\title{
Comentário
}

\section{FAZER MORRER, DEIXAR MORRER}

Carla Rodrigues $^{1}$

Referência do texto comentado: SILVA, S. R. O. Morte impune, luto proibido: vida nua e vida precária em Giorgio Agamben e Judith Butler. Trans/Form/ Açáo: revista de filosofia da Unesp, vol. 43, n. 3, p. 339-360, 2020.

Há muito a ganhar, do ponto de vista teórico e conceitual, na aproximação entre os conceitos de vida nua, em Giorgio Agamben, e vida precária, em Judith Butler. Silva (2020) cumpre muito bem essa função, legando-nos, no entanto, a tarefa de ainda refletir sobre os pontos divergentes que decerto também existem, seja pelo contexto histórico e político em que filósofo e filósofa conceberam suas ideias - Agamben, na Europa pós-queda do Muro de Berlim, Butler nos EUA, pós-11 de setembro -, seja pelo que ambos recusam, no pensamento do outro.

Argumentar que toda política é uma biopolítica é um dos elementos que percorre a grande obra do filósofo italiano Giorgio Agamben, Homo Sacer, escrito entre 1995 e 2015 . No volume II, parte 1, Estado de exceção, Agamben faz referência ao que era então um pequeno artigo de Butler, "O limbo de Guantánamo”, e depois viria a integrar o livro Vida precária, sob o título "Detenção indefinida". Butler é convocada por Agamben justo porque, na argumentação do filósofo italiano, o paradigma do campo de concentração pode ser reencontrado em vigor em muitas democracias contemporâneas,

${ }_{1}^{1}$ Docente na Universidade Federal do Rio de Janeiro e pesquisadora FAPERJ, Rio de Janeiro, RJ Brasil. (D) https://orcid.org/0000-0002-1421-5120 E-mail: carla.ifcs@gmail.com

http://doi.org/10.1590/0101-3173.2020.v43n3.27.p365

\section{(i)}


como nas prisóes mantidas pelos EUA para os prisioneiros da guerra contra o Iraque e o Afeganistão. Nisso, os dois concordam. No argumento da filósofa estadunidense, o limbo era o que permitia a manutenção arbitrária e fora da lei de pessoas não enquadradas, nem como prisioneiros de guerra - e, portanto, sob a proteção da Convenção de Genebra -, nem como prisioneiros do governo americano e, pois, sob a proteção da Constituição dos EUA. A vida precária seria, portanto, exposta à vulnerabilidade, a políticas de privação de direitos e, no limite, à morte.

Mas há uma radicalidade no argumento do filósofo italiano, nem sempre bem compreendida, mesmo por Butler: vida nua é toda vida vinculada à estrutura do ordenamento jurídico, não havendo, por conseguinte, como apelar ao âmbito do direito, a fim de alterar ou diminuir essa condiçáo. Aqui, Butler e Agamben se afastam: a primeira, porque compreende o direito como um campo a ser conquistado, o segundo, por entender que o direito é uma estrutura vazia de conteúdo e, por isso mesmo, disponível como dispositivo para acionar o estado de exceção como paradigma de governo. Butler interpreta a proposição agambeniana como um enfraquecimento das capacidades políticas dos sujeitos, enquanto Agamben considera o direito um brinquedo antigo, cuja função original já se perdeu.

Considero necessário, assim, recuperar o título original de Estado de exceção: "Iustitium. Stato di eccezione". O iustitium é recuperado pelo filósofo, de sorte a perguntar como esse termo do direito público, que havia por tanto tempo designado estado de exceção, tornou-se apenas sinônimo de cerimônia fúnebre. Uma das explicaçóes estaria, segundo ele, no ponto em comum entre os dois - a anomia ou ausência de lei que marca tanto a declaração de estado de exceção quanto o luto público declarado para a suspensáo da ordem vigente e a homenagem ao soberano.

O problema do luto torna-se um novo ponto de encontro entre Butler e Agamben. O direito ao luto para toda e qualquer vida, reivindicado por Butler, pretende marcar a diferença entre vidas que importam e vidas que pesam, vidas vivíveis e vidas matáveis. O luto, pensado por ela como categoria éticopolítica e deslocado da teoria psicanalítica para a filosofia política, cumpre a função de fundamento negativo para a sustentação do que ela chama de "um tênue nós", solo comum a ser reconstruído, considerando o diagnóstico de que o luto é última fronteira erguida para separar a humanidade entre os que têm direito ao estatuto de humanos e os que restam como inumanos e, pois, podem vir a ser eliminados, direta ou indiretamente, seja pelo fazer morrer, 
seja pelo deixar morrer. No momento brasileiro e também mundial, quando a biopolítica parece estar desenhando sua pior face, o artigo "Morte impune, luto proibido: vida nua e vida precária em Giorgio Agamben e Judith Butler" pode nos fornecer chaves de leitura para repensar o que é o contemporâneo.

\section{REFERÊNCIA}

SILVA, Reginaldo Oliveira. Morte impune, luto proibido: vida nua e vida precária em Giorgio Agamben e Judith Butler. Trans/Form/Açáo: revista de filosofia da Unesp, vol. 43, n. 3 p. 339-360, 2020. 
RODRIGUES, C. 